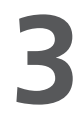

\title{
"New" Questions of Peripherality in Europe or How Neoliberal Austerity Contradicts Socio-Spatial Cohesion
}

\section{Costis Hadjimichalis}

\section{Introduction}

The European Union during the last 20 years has been suffering from a deep multi-dimensional crisis threatening its existence, a crisis which is a combination of economic, social, political and cultural elements. The years of austerity and the economic crisis since 2009, the undemocratic mode of governance and the revival of nationalistic and xenophobic divisions seem to challenge the promises of unity and cohesion. New inequalities are produced while older ones are intensified, highlighting the never-ending importance of uneven geographical development. In this context, the notion of socio-spatial peripherality acquires a renewed importance, free from older binary and static interpretations.

The context of this chapter is largely based on my book: Crisis Spaces: Structures, Struggles and Solidarity in Southern Europe, London: Routledge, 2017.

C. Hadjimichalis $(\bowtie)$

Department of Geography, Harokopio University, Athens, Greece

(C) The Author(s) 2019

T. Lang and F. Görmar (eds.), Regional and Local Development 
It is widely accepted that the socio-spatial production of peripherality is the outcome of the longue durée of uneven and combined development, deeply rooted in the operation of capitalist market forces. As Gunnar Myrdal noted in the 1950s: “...the play of forces in the market normally tends to increase, rather than decrease, the inequalities between regions" (Myrdal 1957, 26). Different processes of peripherality relate also to how particular places are integrated into the international division of labour and are excluded from each time dominant economic activity. Particular institutional regulations may periodically reduce or reinforce unevenness, but without uneven development, capital would surely have stagnated, as David Harvey (1982) long ago noted. However, unevenness across space and consequently the reproduction of socio-spatial peripherality is not restricted to the needs of capital only. It is combined with the uneven ideological imaginations and with the cultural power that constructs the Other as inferior, with the uneven political power of elites and institutions that impose regulations, and with the uneven conditions of social reproduction in unemployment, education, housing and health, among others.

Uneven geographical development as a framework enables us to approach the social production of peripherality in a dialectical way to avoid a static and binary distinction between cores and peripheries and to see peripherality as a contested concept. For example, remoteness and rurality, two major indicators used by the dominant explanations, do not always lead to peripherality. Rural gentrification and the existence of peripheral/marginal groups and places within wealthy areas of cities and regions, challenge these two major indicators. Many other contradictory and multi-scalar processes produce and reproduce socio-spatial peripherality in the context of international and European division of labour. Among those, I note capital's contradiction between fixity and motion, the relative immobility of labour, the production, circulation and realisation of value, path dependency, place-specific devaluations, cultural prejudices and imaginations and finally, institutions regulating all the above (Hudson 2005). Although these processes are key parameters in the reproduction of peripherality, in this chapter I would like to discuss two other parameters, which in my view are equally important, particularly to the recent European crisis-driven conjuncture. Firstly, how 
imaginations of peripherality shape development theories and policies and secondly, how imaginations and development policies may contribute to deepening unevenness and peripherality. I will conclude by raising some questions concerning the current socio-spatial situation in the EU.

\section{$2 \quad$ Imagining and Conceptualising Socio-Spatial Peripherality}

A key starting point is this: "Who frames capitalist development problems and how?". After the 1950s, international development theories, inspired in part by the problems of the Global South, labelled as "Peripheral" all those countries and regions not belonging to the "northern" birthplaces of European and North American capitalism, labelled as the "Core". Theories such as development and underdevelopment, core-periphery, import substitution, strong state intervention in public infrastructure investments and the like, came from this period. Economists, geographers and sociologists started to use a series of indices such as accessibility and transport infrastructure, income and consumption per capita, capital supply, degree of industrialisation, export performance, illiteracy, etc., to measure the distance between "peripheral" regions and countries, with "core" regions as the norm. Measuring development distance between nations and regions through such indices became the new dogma and "peripheral" in general became the new international prototype of backwardness. International development theories were transplanted to the regional scale in the 1960s and the 1970s and replicated similar assumptions and indices to measure regional backwardness. Since then, "peripheral" in economics, economic geography and regional development theories has become synonymous with underdevelopment. This has resulted in three major theoretical problems, with devastating effects that persist today.

The first concerns the indices themselves. Although they appear as neutral, universal and technocratic, they are deeply biased, based on historically and geographically specific social and cultural experiences and choices. Those who use and apply the measures are mainly from the "core developed" countries and regions, from whence the historical roots of European 
and North American imperialism and industrial capitalism originate. They put forward as a prototype the particular development trajectory of those areas, which is, of course, different from those places in the periphery. "Different" here does not necessarily mean lagging, less important or inferior which are definitions deriving from the vantage point of the dominant formulations imposed by the indices. Measuring development through indices ignores the variety of actual uneven capitalist development, which takes different forms in different socio-spatial formations; what Bob Jessop (2011) called "variegated capitalism".

The second theoretical problem concerns the linear, economistic and universal development trajectory assumed by these indices and by those who use them. At one end stand the "core/developed" countries or regions having the highest or best indices, while at the other end are those "peripheral/underdeveloped" places. The dominant assumption is that "lagging" peripheral regions need to "catch-up" with developed ones and to do this, they need modernisation, outside assistance and a lot of effort. Several decades ago, the economist Charles Kindleberger called this model the "gap approach": you subtract the indices of peripheral regions from the core ones and the rest is your development programme. In this model, there is no option for a different development path, no alternatives, and imagination of the "peripherality" as metaphor has entered a self-reinforcing cycle in which it is stereotyped (Massey 2006).

The third theoretical problem concerns explanations of backwardness and peripherality. Developmental problems in peripheral areas are explained, on the one hand, as solely the outcome of internallendogenous factors, such as remoteness, capital scarcity and inadequate technology and infrastructure. Social and cultural factors were added, with local people accused of being "traditional, lazy, irresponsible and less energetic", fuelling negative prejudices. These explanations ignore inter-regional relations with the rest of the country and the world and interventions by particular states and capital interests. On the other hand, peripherality is explained as the sole outcome of imposed exogenous exploitative relations, such as multinational capital and/or particular institutional interventions by core capitalist countries. The role of local social actors is totally ignored, assuming their passivity. However, uneven capitalist 
development in general and the reproduction of peripherality in particular, depends always on the contradictory articulation between internal/endogenous and external/exogenous factors (Hadjimichalis and Hudson 2007, 2014). Cities, regions and countries are not closed, bounded entities, but are open and porous; their firms, people and institutions interact, building relations at multiple scales, from local to global and vice versa. There is a shifting importance between these conditions, which are always uneven and combined in particular places and times, introducing dynamic characteristics dependent on changes in the spatial division of labour, from global to local.

Following these imaginations and conceptualisations, several policies in the 1960s and 1970s were introduced in the global North, and particularly in Europe, to develop regional peripheries. Among them, I recall the building of traffic infrastructure to challenge remoteness; the construction and operation of social and cultural infrastructures such as schools, universities, hospitals, housing and museums to improve conditions of social reproduction; large capital investments to provide employment in planned industrial growth poles or in industrial branch plant economies and many more. In summary, these policies had in common a strong external/exogenous intervention, either from the state or by private capital. For some time, these policies worked in parallel with the wider compound capitalist growth and did manage to ameliorate conditions of peripherality, a period known as "welfare regionalism" largely based on Keynesianism and social democratic political principles. However, major changes in the European and global division of labour, the collapse of the Soviet Union and the Eastern block, the rise of neoliberalism, financialisation and massive de-industrialisation, all acted as catalysts to show, once again, the impasse inherent in these assumptions.

In the 1980s and 1990s, a major paradigm shift occurred in economic geography and regional development. Parallel to slow compound growth and as a reaction to the inadequacies of exogenous national and regional development frameworks, the focus shifted from lagging peripheral regions to cases of regional success and a new scale was introduced, the local. Regions and localities such as Third Italy in northeast-central Italy, Silicon Valley and Orange County in 
California, the 'M4 corridor' in southern Britain and southern Bavaria in Germany became paradigmatic cases, while subsequent research came to include many more examples in other parts of the world. The new analytical framework, known as the "Third Way" of thinking, was now "endogenous" development, in which small firms in these regions/ localities successfully combined market opportunities, supposedly without external assistance (Hadjimichalis 2006, 2017). They succeeded by mobilising locally existing resources (particularly knowledge and learning) and new forms of production organisation such as flexibility and networking. These new industrial spaces highlighted the role of competition and cooperation at the local/regional level, with the assistance of strong endogenous cultural traditions and local institutions and associations. Researchers and policy makers agree that a distinctive feature of these places and localities is the embeddedness of certain non-economic factors such as social capital, trust and reciprocity, based on familiarity, face-to-face exchange, cooperation, embedded routines, habits and norms.

As is by now well known-and so just briefly mentioned herethis 'Third Way of thinking' is identified with two major schools of thought: first the so-called New Economic Geography (NEG) or "geographical economics" and second, New Regionalism (NR). Without forming a coherent body of theory, NR promotes several proposals for "learning, networked and flexible" regions, "innovative and intelligent" regions, "clusters", "creative" cities, "communicative planning" and the like (Storper 1997; Cooke and Morgan 1998; Healey 1997; Amin and Thrift 2005). They appeared within the panoply of local/regional development theories in the 1980s and 1990s. According to both theorists and policy makers, while in the past local/regional development took place endogenously in a spontaneous manner, now it can be designed to implement a policy "from below". International organisations, such as the OECD, World Bank, European Union (EU) and several national governments initiated programmes to promote such policies, using the aforementioned success stories as "best practice".

Perhaps the most important omission from this research framework and much of the "New Regionalism" literature, which really remains unspoken, is the uneven relations among regions/localities, successful 
and unsuccessful alike; in other words the burning question of uneven geographical development under capitalism. This was evident in how little attention was paid to the capitalist crisis that was already visible from the mid-1990s in some of the emblematic localities and regions. Just at the very moment that policy prescriptions based upon the assumed bases of success in these localities were becoming generalised within regional and urban policies across the globe, the conditions on which success was based in these exemplar regions were being eroded (Hadjimichalis and Hudson 2014).

\section{Imagining Backwardness and Dealing with Peripherality in the EU}

Much of the previous discussion finds application in the different phases of EU regional development policies. From the mid-1960swhen the EC's "regional problem" was for the first time identifieduntil the mid-1980s, peripherality was imagined mainly as inadequate infrastructure, degree of industrialisation, unemployment and lack of adequate income. It guided a modest attempt towards redistributive policies that, together with the highly generous CAP, resulted in differentiated regional improvements, particularly in Southern Europe, France and the UK. During this period, European regional development indices were introduced followed by a European universal development trajectory while there was a relative balance explanation of peripherality between endogenous/exogenous factors (Thoidou and Foutakis 2006). This period coincided with the first signs of de-industrialisation and the rise of neoliberalism, first with Thatcherism in the UK and later with ordoliberalism in the then West Germany. ${ }^{1}$

From mid-1985 to the early 2000s, several enlargements added new members and in all EU documents and declarations there was an explosion of interest in conversion and cohesion. The exact meaning and content of the two new terms were ambiguous and contradictory, because the allocation of more funds to peripheral regions aimed to compensate for the prospective loss of their competitiveness. It was a major change in the imagination and conceptualisation of peripherality, 
introducing directly the neoliberal rationale of "regional competitiveness" deriving from the Maastricht Treaty of 1992. Competition among regions introduced indirectly the endogenous analytical framework. Many concepts of "Third Way" thinking, particularly those of learning, innovative and intelligent regions, made their appearance in policy recommendations.

From the early 2000s to 2014, we lived in the era of the Lisbon Treaty, the enlargement to 28 members and the euro crisis. The Lisbon Treaty contributed directly to weaken the promotion of the, already illfunded, cohesion objective, while the euro crisis and, after 2015, the refugee crisis, changed dramatically what we once knew as United Europe. From a spatial point of view, since the 2000s, regional unevenness in the EU has increased and this increase highly correlates with particular EU policies. During the early euro years, 2000-2013, all development policies of the EU, including regional policies, were subsumed under the Lisbon strategy. It was assumed that Regional Competitiveness, as the main development axis, would provide "growth and jobs". All EU regions became eligible for funding and although extra funding was available for the less developed regions, this policy shift benefited peripheral regions in the East and the South the least, although supposedly, drafted for them. The euro crisis in the regions of Southern Europe and persisting structural deficiencies in many ex-socialist regions of the East fuelled regional divergence during the period 2000-2015 (European Commission 2017). The sequel to this story is Europe 2020, a strategy promoting "smart, sustainable, inclusive growth" (European Commission 2010). By then, everything in Europe was supposed to be "smart" to "improve the business environment". In addition, all policies should follow neoliberal "fiscal discipline" and finally: "Fiscal consolidation and long-term financial sustainability will need to go hand in hand with important structural reforms, in particular of pension, health care, social protection and education systems" (European Commission 2010, 24). In short, austerity.

The major problem with cohesion funds is the contradiction between seeking neoliberal macro-economic policies that impose austerity while pursuing solidarity and economic and social cohesion. The cornerstone of any regional development programme consists of socio-spatial redistribution 
aiming at reducing unevenness and socio-spatial injustices, something that is inconsistent, theoretically and practically, with austerity.

The latter is documented in the 7th Report on economic, social and territorial cohesion (European Commission 2017) with evidence of economic and social gaps between Southern/Eastern Europe and regions in more developed nations in Northern and Western Europe. Using known indicators such as, among others, GDP per head, general and youth unemployment, education and training, poverty and exclusion, the report highlights the increase in regional inequality in all the above indices during the period 2000-2015, i.e. when neoliberal austerity was generalised across the EU. The Report also identifies four "income clubs": very high, high, medium and low income "clubs" (p. 23). The geography of these "clubs" corresponds to the familiar uneven development pattern, known since the 1990s. Very high- and high-income regions are located in a band from London through Paris, the Benelux and Germany, down to some northern Italian regions and up to Scandinavian regions. Medium- and low-income regions instead are located in Southern and Eastern Europe. General and youth unemployment, poverty and social exclusion show a similar geographical pattern. Furthermore, the EU itself promotes neoliberal policies and, following the new Economic Governance established in 2012, could use cohesion funds as a threat tool, since Brussels is allowed to suspend funding for countries that fail to meet their deficit targets. Thus, it is hardly surprising that after 30 years, regional and cohesion programmes have failed to achieve their main goal: creating a more economically homogeneous Europe. The main reason behind this failure is austerity cutting across all these indicators, depending, of course, on the particular variety of neoliberalism applied in each country.

The 2014 reform of EU Cohesion Policy (EUCP) to strengthen the efficiency of the policy and to increase the performance of the recipient regions, made the whole process more complicated. The three pillars of the new EUCP consist of "smart, sustainable and inclusive growth". The first two pillars of the 2020 agenda are reduced to the goal of regional economic competitiveness, whilst the third requires solidarity among member states and regions in contradiction of the former two pillars. In the post-2014 period, two types of conditionality are in operation. 
First, the macro-economic conditionality operates as part of the Fiscal Pact, imposing economic surveillance of budgetary limitations, i.e. imposing permanent austerity. Second, there will be conditionalities operating inside the context of the EUCP. All countries have to spend allocated funds in two years; otherwise, they must return the money. The reorientation of post-2014 EUCP promotes an endogenous approach that views "region" in functional terms: a bounded entity that determines economic action and every region should "compete" and achieve convergence through growth. A familiar approach that re-introduces endogenous processes also emphasising "Third Way" concepts such as non-economic factors such as knowledge (especially tacit), capacities to generate consensus and trust and social capital, innovative capacities of firms and organisations and high labour skills (Hadjimichalis 2006).

The objectives and discourses of "growth through competitiveness, innovation and flexibility" have superseded the pursuit of cohesion and convergence through redistribution. The Lisbon Treaty and Europe 2020 contributed directly to the weakening of the promotion of the cohesion objective as part of EU policies. Despite the rhetoric in documents and the Brussels jargon, the reproduction of socio-spatial peripherality via austerity and uneven geographical development is alive and well.

\section{In What Sense Peripherality in the Twenty-First Century?}

I borrow the above question from Doreen Massey's late 1970s' seminal paper, where she introduces the concept of spatial division of labour. Among many other points, Massey $(1979,236)$ argued that:

...'The economy' of any given local area will (...) be a complex result of the combination of its succession of roles within the series of wider, national and international, spatial divisions of labour.

The current situation in the various peripheries of Europe, which has stayed more or less stable since the 1990s, strongly depends on the "succession of roles" within the spatial division of labour, from local to 
global, incorporating endogenous and exogenous factors. In this respect, uneven conditions of peripherality in the twenty-first century are hardly "new" and build upon major restructuring processes that have taken place in recent decades. Among these, I can briefly mention the uneven enlargement of the EU towards Eastern Europe; the combination of de-industrialisation and de-localisation of productive activities resulting in unemployment and regional decline in "traditional" agglomerations and the rise of new ones; a massive class, gender, age and ethnic recomposition of the EU labour markets including incoming migrants; several institutional restructurings such as the Maastricht Treaty, trade regulations such as the Outward Processing Trade; and finally, the major financial break with the introduction of the euro. This restructuring in the spatial division of labour resulted in deepening uneven development between and within countries that further marginalised the position of EU peripheries (see also Smith 2013).

As shown in the previous section, regional/local development policies have been inadequate in dealing with peripherality questions. The major crisis of 2009-2010 in Europe and beyond introduced three other important factors visible since the 1990s but acquired critical importance after the global turmoil in 2009. These are: (a) financialisation, (b) the rise of a new rentier economy, and (c) private and public debt that rarely entered the discussion of local/regional development theories and policies. From the late 1980s onwards, financialisation took the lead with the help of active intervention by the state (Hudson 2010; Sayer 2015). The productive sector in EU regions exhibited slow growth, but did so variably between regions, with German regions and their satellites the obvious example. Instead, rent-seeking activities such as investments in bonds and securities, in privatised public utility companies, in insurance and in real estate and land grabbing started dominating EU economies. Deregulation of old welfare apparatuses and re-regulation for the benefits of capital plus technological innovation helped the financial sector to create new "products" and to attract the majority of surplus capital. Moreover, welfare cuts, lower wages and credit card expansion made middle-, working-class households become increasingly dependent on formal finance, and they incurred debt in order to secure access to vital goods. Finally, due to diminishing public 
revenues, states, regions and municipalities began to depend more and more on bank loans or investments in securities to finance their daily operations and to build speculative real estate. Their debt accumulated while financialisation proceeded and in this way, private, public and municipal debt became a mechanism for capturing social wealth and political control. As the French Regulation School and Maurizio Lazzarato argued, it was a major shift in the "regime of accumulation", away from the Fordist and post-Fordist productive regime towards the "regime of accumulation with financial and debt dominance" (Aglietta 2000; Boyer 2000; Lazzarato 2012).

The above shift is highly uneven geographically but reproduces the familiar polarisation in the EU discussed in the previous section. Some regions in central-north Europe retained their productive capacity, exported performance, and accumulated surpluses, while the peripheries of Southern and Eastern Europe accumulated debt. The rise of the so-called FIRE economy (finance, insurance and real estate) increased the importance of metropolitan regions and further marginalised rural peripheries. None of these developments attracted attention and so the crisis of 2009-2010 exploded out of a deep sleep.

In addition, the authoritarian and unaccountable mode of EU Governance facilitated the rise of technocracy that de-politicised all development problems. Since the 2000s, neoliberal and "Third Way" regional development theories and policies operated on the same track so that both promoted policies for a competitive and entrepreneurial city and region. Thus, the way they formulated Doreen Massey's original question "In what sense a regional/peripheral problem" has been de-politicised when a frontal attack against neoliberal policies was needed. The trouble in these times is that most policy makers have no idea who Keynes was and what he really stood for and do not know Myrdal's "cumulative causation" and "backwash effects"; uneven development sounds "too political" while the understanding of Marx is negligible.

So what is the response of the dominant EU institutions to the above developments and critical comments? I am afraid very inadequate indeed. Unable or unwilling to face the results of their own practices, European leaders met in March 2017 in Rome to celebrate the 
EU's 60th "birthday". Among the celebratory speeches and in the Rome 2017 Declaration, three important concepts, the lack of democracy, austerity and the euro crisis, were absent. It is hardly surprising that political leaders had little self-critical to say about the issue. Instead, in classical Brussels' jargon, the Declaration promised that the Union "will act together, at different paces and intensity where necessary". This is how the European establishment covered the proposal for a "multispeed" Europe, launched by German, French, Italian and Spanish elites. The proposal, known also as "variable geometries", "differentiated integration" and "concentric circles" had been around for several years in Brussels and in meetings of experts, but it was opposed by British and some other countries' elites. It has been indirectly included in the Maastricht Treaty, the Schengen agreement and finally in the Eurozone. These agreements gave the power to individual states to join policies and treaties selectively on a voluntary basis and, in combination with neoliberalism and financialisation, made clear that real integration and convergence was not an EU target. Uneven development, covered as always with nice words about social and territorial cohesion, was finally de facto accepted by the EU and silently framed as the deserved price for those not willing to join proposed policies.

We don't yet know the exact ingredients of the new proposal, except that it openly challenges one of the foundational principles of the then European Common Market, agreed in Rome in 1957, namely that all countries are equal. At that time, European integration was a hegemonic project in the sense that the dominant powers promoted their class interests, while looking after the popular masses via social cohesion, redistribution and social welfare. Of course, socio-spatial equality existed only in principle and in the course of time capital accumulation and political intervention (e.g. the Maastricht Treaty and the introduction of the euro) made some countries, regions and social groups within them "more equal" than others. Neoliberalism and its German version, ordoliberalism now dominant in the EU, violently changed the remnants of the old hegemonic project and guided the EU and particularly the Eurozone into crises, ceasarism and austerity. At the beginning of the twenty-first century, dominant class interests still lead the project but without hegemony. The widespread de-legitimisation of EU policies 
that came unfortunately mainly from ultra-right xenophobic political forces and less so from left anti-systemic movements and parties is indicative of the present condition.

In the 2017 celebrations in Rome, inequality and uneven development were cynically packed in fancy wrapping and offered as the solution to the EU malaise, as a positive new paradigm supposedly facing forwards while refusing to look backwards that is, without "coming to terms with continuing uneven development in Europe", as Ray Hudson (2017) argues. Some of the Heads of State supporting the idea argued that "multiple speeds already exist in Europe", and Angela Merkel added, "we cannot stop countries wishing to increase their speed of integration". Their cynicism is blind to the fact that the enterprise of European integration, instead of moving at multiple speeds, is at a standstill, or worse, in reverse. Furthermore, it is not accidental that EU leaders and the class interests they represent avoided coming to terms with the existing undemocratic EU structure. In the Rome Declaration, they promised to "promote democratic, effective and transparent decision-making" in clear contradiction to the acceptance of Treaties and the practices of EU institutions responsible for applying undemocratic and opaque procedures.

I am aware that the current elitist ruling order in Europe and the stock of regional development policies they use are incapable of dealing effectively with these issues and of restoring confidence and solidarity among sharply divided populations. Therefore, a major political change away from neoliberalism and austerity is needed as the necessary precondition, but perhaps is not enough to handle the "new" questions of peripherality. Thus, besides much-needed macro-political changes, I propose to look also inward, into our field. Much contemporary regional development theory and policy were crafted in the 1990s, a period of relative stability, integration and growth that ended in economic crisis and high uncertainty. Existing mainstream theories and policies are weak and proved incapable of explaining these conditions and this demands fresh thinking. So, a paradigm shift is required, one that goes back to earlier political economy theories and policies, avoiding mistakes of the past; and one that looks forward integrating lessons from the euro and the refugee crisis and the effects from austerity policies. ${ }^{2}$ 
The previous critical comments could be seen as an invitation to start thinking towards the required shift, in which we should fight to repoliticise regional development issues by asking who is gaining/losing and why, because neither success nor failure is entirely endogenous or exogenous. In other words, if a region fails it is not only of "its" own endogenous problems but it is also part of the price of others "succeeding" to become centres, materially or imagined. We should also pursue policies and actions that challenge socio-spatial injustice and the lack of democracy and accountability, both at home and in EU institutions. These steps by themselves cannot challenge the neoliberal dogma, but at least could open new paths of knowledge and emancipation, so important nowadays for younger researchers and policy makers. Not an easy task but one worth the effort. After all, experience tells us that lost fights are only those that were not fought.

\section{Notes}

1. Ordoliberalism became the dominant mantra of law and order in Germany after the 1980s and was characterised by the following features: strong central state intervention to secure competition; an independent central bank committed to monetary stability and low inflation; a balancing of tax revenue against government expenditure; privatisation of public services and public assets; deregulation of the labour market and putting in place a minimum wage. The State is necessary to achieve the market ideal, but a particular kind of State. Ordoliberals have limited faith in democracy and instead they strongly believe in independent, networked institutions that are unaccountable and operate parallel to the State. The trouble with ordoliberalism, as Aziz (2015) notes, is that when situations/basic parameters change, the rules of independent institutions stay the same, and if that means the problem is not solved, then so be it. This is how the EU and Eurozone operate nowadays.

2. For reason of space, I cannot explain here further the requirements of this shift, but the interested reader should consult Hadjimichalis and Hudson (2014) and Hadjimichalis (2017). 


\section{References}

Aglietta, Michel. 2000. "Shareholder Value and Corporate Governance: Some Tricky Questions." Economy and Society 29 (1): 146-59. https://doi. org/10.1080/030851400360596.

Amin, Ash, and Nigel Thrift. 2005. "What's Left? Just the Future." Antipode 37 (2): 220-38. https://doi.org/10.1111/j.0066-4812.2005.00488.x.

Aziz, John. 2015. “The Trouble with Ordoliberalism.” Pieria, July 29. http:// www.pieria.co.uk/articles/the_trouble_with_ordoliberalism.

Boyer, Robert. 2000. "Is a Finance-Led Growth Regime a Viable Alternative to Fordism? A Preliminary Analysis." Economy and Society 29 (1): 111-45. https://doi.org/10.1080/030851400360587.

Cooke, Philip, and Kevin Morgan. 1998. The Associational Economy: Firms, Regions, and Innovation. Oxford: Oxford University Press.

European Commission. 2010. "Europe 2020: A Strategy for Smart, Sustainable and Inclusive Growth." COM (2010) 2020 Final. Brussels: European Commission. http://ec.europa.eu/eu2020/pdf/COMPLET\%20 EN\%20BARROSO\%20\%20\%20007\%20-\%20Europe\%202020\%20 $-\% 20 \mathrm{EN} \% 20$ version.pdf.

European Commission. 2017. "My Region, My Europe, Our Future. Seventh Report on Economic, Social and Territorial Cohesion.” Luxembourg: Publications Office of the European Union. http://ec.europa.eu/regional_ policy/sources/docoffic/official/reports/cohesion7/7cr.pdf.

Hadjimichalis, Costis. 2006. "Non-economic Factors in Economic Geography and in 'New Regionalism': A Sympathetic Critique." International Journal of Urban and Regional Research 30 (3): 690-704. https://doi.org/10.1111/j. 1468-2427.2006.00683.x.

Hadjimichalis, Costis. 2017. Crisis Spaces: Structures, Struggles and Solidarity in Southern Europe. London: Routledge.

Hadjimichalis, Costis, and Ray Hudson. 2007. "Rethinking Local and Regional Development. Implications for Radical Political Practice in Europe." European Urban and Regional Studies 14 (2): 99-113. https://doi. org/10.1177/0969776407076290.

Hadjimichalis, Costis, and Ray Hudson. 2014. "Contemporary Crisis Across Europe and the Crisis of Regional Development Theories." Regional Studies 48 (1): 208-18. https://doi.org/10.1080/00343404.2013.834044.

Harvey, David. 1982. The Limits to Capital. Oxford: Blackwell. 
Healey, Patsy. 1997. Collaborative Planning: Shaping Place in Fragmented Societies. Basingstoke: Macmillan.

Hudson, Ray. 2005. Economic Geographies. Circuits, Flows and Spaces. London: Sage. http://dx.doi.org/10.4135/9781446216743.

Hudson, Michael. 2010. "The Transition from Industrial Capitalism to a Financialized Bubble Economy.” Working Paper 627, Levy Economics Institute. http://ssrn.com/abstract=1695039.

Hudson, Ray. 2017. "Facing Forwards, Looking Backwards: Coming to Terms with Continuing Uneven Development in Europe." European Urban and Regional Studies 24 (2): 138-41. https://doi.org/10.1177/0969776416689230. Jessop, Bob. 2011. "Rethinking the Diversity and Variability of Capitalism: On Variegated Capitalism in the World Market." In Capitalist Diversity and Diversity Within Capitalism, edited by Christel Lane and Geoffrey T. Wood, 211-37. London: Routledge.

Lazzarato, Maurizio. 2012. The Making of the Indebted Man: An Essay on the Neoliberal Condition. Los Angeles: Semiotext(e).

Massey, Doreen. 1979. "In What Sense a Regional Problem?" Regional Studies 13 (2): 233-43. https://doi.org/10.1080/09595237900185191.

Massey, Doreen. 2006. "Space, Time and Political Responsibility in the Midst of Global Inequality.” Erdkunde-Archive for Scientific Geography 60 (2): 89-95. https://doi.org/10.3112/erdkunde.2006.02.01.

Myrdal, Gunnar. 1957. Economic Theory and Under-Developed Regions. London: Duckworth.

Sayer, Andrew. 2015. Why We Can't Afford the Rich. Bristol: Policy Press.

Smith, Adrian. 2013. "Europe and an Inter-Dependent World: Uneven GeoEconomic and Geo-Political Developments." European Urban and Regional Studies 20 (1): 3-13. https://doi.org/10.1177/0969776412463309.

Storper, Michael. 1997. The Regional World: Territorial Development in a Global Economy. New York: Guilford Press.

Thoidou, Elisavet, and Dimitris Foutakis. 2006. "Metropolitan Thessaloniki and Urban Competitiveness: Programming, Transformation and Implementation of a 'Vision' for the City." Geographies 12: 25-46 (in Greek). 
Open Access This chapter is licensed under the terms of the Creative Commons Attribution 4.0 International License (http://creativecommons. org/licenses/by/4.0/), which permits use, sharing, adaptation, distribution and reproduction in any medium or format, as long as you give appropriate credit to the original author(s) and the source, provide a link to the Creative Commons license and indicate if changes were made.

The images or other third party material in this chapter are included in the chapter's Creative Commons license, unless indicated otherwise in a credit line to the material. If material is not included in the chapter's Creative Commons license and your intended use is not permitted by statutory regulation or exceeds the permitted use, you will need to obtain permission directly from the copyright holder. 